\title{
MODEL LATIHAN DRIBBLE BOLABASKET UNTUK PEMULA
}

\author{
Raden Juan Suryadi Yusuf ${ }^{1 *}$, Ricky Wibowo ${ }^{2}$ \\ ${ }^{1}$ Universitas Pendidikan Indonesia \\ email : juanyusuf77@yahoo.com
}

\begin{abstract}
Abstrak
Penelitian ini berfokus pada pengungkapkan apakah model latihan keterampilan dribble bolabasket untuk pemula dapat meningkatkan keterampilan dribble bolabasket atlet pemula. Metode Penelitian menggunakan metode Research \& Development (R\&D). Penelitian ini dilaksanakan pada atlet bolabasket Club Garuda Kota Bandung. Penelitian ini menggunakan penelitian dan pengembangan dari Borg and Gall. Instrumen yang digunakan adalah catatan lapangan dan evaluasi. Pemecahan masalah penelitian ini adalah model latihan keterampilan dribble bolabasket untuk pemula dapat meningkat. Berdasarkan hasil penelitian didapat test awal 13.07 detik dan test akhir 10.67 detik. Berdasarkan hasil pengolahan dan analisis data, maka kesimpulan dari penelitian ini adalah dengan menggunakan Model latihan dribble bolabasket dapat dikembangkan dalam latihan dribble bolabasket untuk atlet pemula dan Model latihan dribble bolabasket efektif dapat meningkatkan hasil test dribble bolabasket. Saran yang diberikan yaitu untuk meningkatkan keterampilan dribble bolabasket menggunakan model latihan dribble sudah jelas terbukti peningkatannya serta untuk lebih meningkatkan pada hasil yang optimal dilakukan pengolahan produk.
\end{abstract}

Kata kunci: Pengembangan, Model, \& Keterampilan Dribble Bolabasket

\begin{abstract}
This study focuses on disclosing whether the adoption of developing a dribble exercise model for beginners in basketball exercise can improve the skill of a novice athlete's dribble basketball. Research Methods that the researcher proposed is a research approach by using Research \& Development $(R \& D)$ development method. This research was conducted at athletes basketball Club Garuda Bandung. Created using Singer Research Methods development Research \& Development $(R \& D)$, from Borg and Gall. Instruments used in this study are field notes, documentation, and evaluation. Problem solving in this research is the application of developing dribble training model for beginners in basketball sport practice can improve the skill of dribble basketball beginner athlete. Based on the research results obtained athlete test results in pretest 13.07 seconds and the final test 10.67 seconds. Based on the results of processing and data analysis, the conclusion of the results of this study is to use dribble basketball exercise model can be developed in the dribble basketball exercise for beginner athlete and dribble basketball training model can effectively improve the results of dribble basketball test for beginner athletes. Improving dribble basketball skills using dribble training model has clearly proven its improvement as well as to further improve again on optimal results done with product processing.
\end{abstract}

Keywords: Development, Model \& Skill Basketball Dribble.

\section{PENDAHULUAN}

Untuk saat ini olahraga bolabasket menjadi olahraga yang berkembang paling pesat di dunia, baik di Indonesia olahraga bolabasket menjadi salah satu cabang olahraga yang berkembang dengan baik di masyarakat yang meliputi semua kalangan dan usia. Olahraga bolabasket memberikan tingkat 
koordinasi gerak yang cukup kompleks. Seperti berjalan, berlari, melompat, menembak, melempar, dan menangkap. Konsep dalam permainan bolabasket adalah memasukan bola kedalam keranjang lawan sebanyak mungkin dan dimainkan oleh dua tim yang masing-masing terdiri dari lima pemain. Tujuan dari masing-masing tim adalah untuk mencetak angka ke keranjang lawan dan berusaha mencegah tim lawan mencetak angka.

Untuk meningkatkan prestasi tentu perlu adanya peningkatan teknik dasar olahraga bolabasket seperti: mengoper, menggiring bola dan sebagainya sesuai dengan peraturan yang berlaku. Melalui macammacam teknik, pemain mendapat kesempatan untuk mengimprovisasi gerakan seperti: bounce pass, lay up, spin dribble, dan behind the back dribble. Olahraga bolabasket adalah olahraga tim yang membutuhkan kerjasama didalamnya juga penguasaan teknik dasar individual yang menjadi salah satu point penting. Dribble adalah salah satu teknik dasar yang paling dominan dilakukan dalam olahraga bolabasket. Karena kegunaannya sendiri yaitu untuk membawa bola ke depan atau ke daerah lawan selain dengan passing. Teknik menggiring bola merupakan bagian yang tidak terpisahkan dari permainan bolabasket. Menggiring bola merupakan senjata penyerangan yang harus dikuasai oleh setiap pemain. Meningkatkan kemampuan menggiring bola, pemain perlu memiliki ketangkasan dan kelincahan dalam bermain. Kelincahan pemain berpengaruh pada kemampuan tim. Kelincahan tersebut bisa digunakan pada teknik dribbel untuk melewati lawan dengan cepat, jarang seorang atlet bisa melakukan kelincahan dengan melakukan dribbel karena ketika mendribble bola atlet tersebut tidak bisa mengontrol bola ketika dipantulkan ke lantai. Contohnya pada olahraga bolabasket yaitu adalah seorang pemain yang sedang melakukan dribbling dengan tiba-tiba merubah arah dribblingnya dengan cepat untuk melewati seorang lawan dan mencetak angka. Itu karena dalam pergerakan tersebut ditopang oleh tungkai yang menjadi sebuah penggerak tubuh dalam merubah arah. Kelincahan dalam cabang olahraga bolabasket sangatlah berpengaruh karena karakteristik bolabasket yang mempunyai unsur menggiring bola (dribble), mengoper (passing), menangkap bola (catching), dan menembak (shooting). Dengan karakteristik tersebut permainan bolabasket membutuhkan kelincahan yang tinggi untuk mengecoh lawan dengan dribble atau dengan pergerakan tanpa bola.

Beragamnya keterampilan dalam permainan bolabasket memberikan banyak pilihan bagi pelatih untuk menentukan keterampilan mana yang akan dicapai. Keterampilan dasar biasanya diterapkan dalam latihan untuk pemula. Seperti keterampilan menggring (dribbling), mengoper (passing) dan menangkap bola (catching). Keterampilan tersebut dapat menjadi pondasi utama agar terlaksananya permainan dengan baik. Keterampilan menggring bola (dribbling) adalah keterampilan yang menyenangkan dan mengagumkan, tetapi akan menjadi sesuatu yang menakutkan jika dipakai untuk menunjukan kemampuan personal. Maksudnya bila seorang atlet sudah menguasai keterampilan dribbling dengan baik, kemudian ingin menunjukan kemampuan personal, maka atlet tersebut akan menghiraukan teman yang lainnya dan akan menghiraukan nilai kerjasama dalam permainan bolabasket. Diungkap oleh Kosasih (2010:38), bahwa Dribble pada dasarnya adalah gerakan yang harus mengarah pada ring. Namun dribble juga dapat menjadi cara untuk membuka peluang bagi pemain lain agar mendapat ruang untuk mencetak skor dan dribble adalah pergerakan bola hidup yang disebabkan oleh seorang pemain yang sedang menguasai bola dengan melempar, menepis, menggelindingkan bola ke lantai atau dengan sengaja melemparkan bola ke papan pantul.

Pengembangan model latihan merupakan salah satu bentuk dari penerapan pendekatan sistem dalam kegiatan latihan yang berdasarkan suatu proses sistematis yang menghasilkan suatu sistem latihan yang siap untuk digunakan dengan tepat. Produk latihan dengan pengembangan model harus dilakukan secara bertahap, menyeluruh dan komperhesif dengan tujuan untuk meningkatkan kompetensi atau hasil latihan pemain. Pertimbangan model latihan ini harus masuk keranah tujuan latihan yang mengisyaratkan pemain sebagai subyek latihan, pengorganisasian latihan, peyampaian latihan, pengelolaan latihan dengan memperhatikan faktor tujuan latihan dan hambatan latihan dengan tujuan 
untuk memperoleh latihan yang efektif dan efisien. Berdasarkan hal tersebut maka model merupakan suatu bentuk tiruan dari aslinya dengan tujuan memperoleh sesuatu yang ideal dengan memperhatikan faktor fisiologis, fasilitas, dan lingkungan sosial atlet. Melalui model-model latihan ini atlet diberikan kebebasan dalam memilih model latihan yang dapat membantu dalam kegiatan latihan dribble bolabasket. Melihat konsep yang ada dengan demikian model latihan merupakan cara atau variasi yang dilakukan guna mencapai tujuan perbaikan sistem organisasi dan fungsinya untuk mengoptimalkan prestasi atau penampilan olahraga. Adapun tujuan dari penelitian dan pengembangan terhadap Model latihan teknik dribble cabang olahraga bolabasket pada pemula adalah sebagai untuk mengembangkan model latihan teknik dribble cabang olahraga bolabasket pada pemula dan untuk menguji keefektifan model latihan teknik dribble cabang olahraga bolabasket pada pemula.

\section{METODE}

Penelitian yang peneliti ajukan ini merupakan penelitian yang menggunakan pendekatan deskriptif kualitatif dengan menggunakan metode Penelitian pengembangan Research \& Development (R\&D). Penelitian pengembangan Research \& Development (R\&D) merupakan suatu proses yang dipakai untuk mengembangkan dan memvalidasi produk pendidikan. Ditinjau dari tujuannya untuk menghasilkan atau mengembangkan suatu produk, penelitian ini dapat dIgolongkan sebagai penelitian pengembangan. Penelitian pengembangan adalah metode penelitian yang digunakan untuk menghasilkan produk tertentu, dan menguji keefektifan produk tersebut. Pengembangan meliputi kegiatan percobaan dan penyempurnaan terhadap suatu produk pengembangan. Hasil akhir dari kegiatan penelitian dan pengembangan adalah model latihan teknik dribble cabang olahraga bolabasket pada pemula. Tentunya hasil akhir dari penelitian ini akan menghasilkan desain model latihan baru yang lengkap, kreatif dan variatif, sehingga dapat digunakan dalam referensi bagi pelatih maupun atlet dalam proses latihan. Penelitian model latihan dribble ini menggunakan model penelitian dan pengembangan (Research and Development) dari Borg dan Gall yang terdiri dari sepuluh langkah. Penelitian ini akan dilaksanakan di Gor Trilomba Juang Kota Bandung dengan subyek atlet club Garuda Kota Bandung tingkat pemula yang aktif mengikuti proses latihan. Penelitian ini dilakukan selama dua bulan. Waktu pelaksanaan penelitian tersebut dilaksanakan pada Bulan Maret 2017 sampai dengan Bulan Mei 2017.

\section{HASIL DAN PEMBAHASAN}

Hasil dari pengembangan model keterampilan dribble bolabasket yang diuji cobakan pada atlet pemula club Garuda Kota Bandung ditulis dalam bentuk buku panduan model latihan. Buku tersebut menyajikan berbagai model latihan keterampilan dribble bolabasket untuk atlet pemula, latihan yang akan disajikan dengan beberapa model latihan. Setiap model latihan keterampilan dribble bolabasket untuk atlet pemula disajikan dengan bentuk yang sama tetapi langkah-langkah yang berbeda di setiap model latihan. Dengan demikian model latihan yang bervariatif diharapkan akan tercapai tujuan dari latihan yang telah direncanakan.

Secara keseluruhan terdapat dua tujuan umum yang hendak diungkapkan dalam studi pendahuluan, yaitu:

a. Model latihan keterampilan dribble bolabasket dapat dikembangkan dan diterapkan dalam latihan pada atlet pemula untuk meningkatkan keterampilan dribble bolabasket.

b. Pentingnya latihan bolabasket dengan model variasi latihan yang efektif, efisien dan menarik. 
Dengan dasar tujuan umum diatas kemudian hasil studi pendahuluan atau temuan lapangan selanjutnya dideskripsikan dan dianalisis sehingga dapat diperoleh suatu rumusan hasil data yang telah dikumpulkan. Rumusan hasil ini bersifat deskriptif dan analitis. Berikut ini akan dijabarkan mengenai hasil analisis kebutuhan dan temuan lapangan yang diperoleh peneliti.

\begin{tabular}{|c|c|c|}
\hline No & Butir Pertanyaan & Temuan \\
\hline 1 & $\begin{array}{l}\text { Apa saja yang diajarkan dalam } \\
\text { latihan dribble bolabasket pada } \\
\text { atlet? }\end{array}$ & $\begin{array}{l}\text { Pelatih sudah memberikan berbagai macam jenis } \\
\text { latihan dribble bolabasket }\end{array}$ \\
\hline 2 & $\begin{array}{l}\text { Apakah materi latihan dribble } \\
\text { bolabasket selalu diberikan } \\
\text { pada latihan? }\end{array}$ & $\begin{array}{l}\text { Pada dasarnya materi latihan dribble bolabasket } \\
\text { telah diberikan sewaktu latihan dilakukan, akan } \\
\text { tetapi atlet sering terlihat tidak bersemangat dan } \\
\text { cepat merasa bosan }\end{array}$ \\
\hline 3 & $\begin{array}{l}\text { Media/alat yang digunakan } \\
\text { untuk penyampaian latihan } \\
\text { dribble bolabasket? }\end{array}$ & $\begin{array}{l}\text { Sampai saat ini yang digunakan dalam latihan } \\
\text { dribble bolabasket adalah bolabasket. }\end{array}$ \\
\hline 4 & $\begin{array}{l}\text { Antusiasme atlet dalam } \\
\text { mengikuti latihan bolabasket? }\end{array}$ & Atlet sangat antusias pada waktu mengikuti latihan. \\
\hline 6 & $\begin{array}{l}\text { Upaya yang sudah dilakukan } \\
\text { agar atlet tertarik dalam latihan } \\
\text { dribble bolabasket? }\end{array}$ & $\begin{array}{l}\text { Selama ini pelatih hanya memberikan penekanan } \\
\text { melalui perkataan, dan memberikan variasi latihan } \\
\text { sebatas yang pelatih miliki }\end{array}$ \\
\hline 7 & $\begin{array}{l}\text { Apakah dibutuhkan model } \\
\text { latihan dribble bolabasket yang } \\
\text { lebih bervariasi? }\end{array}$ & $\begin{array}{l}\text { Secara umum pelatih sangat membutuhkan berbagai } \\
\text { macam model latihan dribble bolabasket yang } \\
\text { variatif. Agar atlet dapat lebih termotivasi dalam } \\
\text { mengikuti latihan yang diberikan. }\end{array}$ \\
\hline
\end{tabular}

Hasil studi pendahuluan atau temuan lapangan selanjutnya dideskripsikan dan dianalisis sehingga hasil ini bersifat deskriptif dan analitis, dengan mengacu pada tujuan studi pendahuluan. Berikut ini akan dijabarkan mengenai hasil analisis kebutuhan dan temuan lapangan yang diperoleh peneliti. Uji coba kelompok kecil akan diperoleh data tentang kemudahan model latihan dribble bolabasket untuk atlet pemula. Subjek uji coba dalam uji coba kelompok di lakukan di dua sekolah yaitu: 1) Club Metro Bandung , 2) Club Scorpio Bandung dan 3) Club Akademi Bandung Utama dengan jumlah subyek sebanyak total 24 orang.

Berdasarkan evaluasi ujicoba kelompok kecil yang dilakukan oleh peneliti dapat disimpulkan yaitu pada dasarnya semua variasi dapat diterapkan, akan tetapi harus disesuaikan dari tingkatan yang mudah ke yang sulit agar kemampuan anak dapat meningkat. Berikut akan disajikan pengolahan data hasil evaluasi uji coba kelompok besar terhadap produk pengembangan model latihan dribble bolabasket untuk pemula. Pada uji coba kelompok besar menggunakan 30 atlet dari 2 Club Bolabasket. Kegiatan uji coba kelompok besar dilaksanakan pada bulan April 2017. Penelitian dilakukan di 2 Club yaitu:

1) Club Garuda Bandung

2) Club Patriot Beezer Kabupaten Bandung 
Berdasarkan hasil output dengan menggunakan Ms Excel bahwa kecepatan rata-rata dribble bolabasket sebelum diberikan model latihan dribble bolabasket adalah 13.06633333 detik $\approx 13.07$ detik dan setelah diberikan perlakuan dengan model latihan dribble bolabasket 10.673 detik $\approx 10.67$ detik. Koefisien korelasi latihan dribble bolabasket sebelum dan sesudah diberikan model latihan dribble bolabasket dengan p-value $0.001211972<0.05$. Jadi kesimpulannya singnifikan. Dalam uji signifikansi perbedaan dengan Ms Excel dapat hasil t-hitung $=3.171524099$, df $=58$ dan p-value $=$ $0.002423944<0.05$ yang berarti terdapat perbedaan yang signifikan hasil belajar dribble bolabasket atlet sebelum dan sesudah diberi model latihan dribble bolabasket. Berdasarkan keterangan tersebut dapat dikatakan bahwa model latihan dribble bolabasket yang dikembangakan efektif dan dapat meningkatkan hasil belajar dribble bolabasket untuk pemula. Berikut perbandingan rata-rata dari hasil belajar sebelum pemberian treatmen dan sesudah pemberian perlakuan dengan model-model latihan dribble bolabasket.

Produk yang dikembangkan ini bertujuan untuk membantu meningkatkan tercapainya tujuan latihan olahraga bolabasket khususnya materi dribble untuk atlet pemula yang di sesuaikan dengan kebutuhan dalam latihan dribble. Model ini dibuat berdasarkan tingkat kebutuhan atlet, maka dalam model ini penerapannya dilakukan dengan prinsip pendekatan yang menyeluruh pada latihan dribble. Hasil ujicoba tahap kedua penggunaan model ini ternyata menghasilkan target yang diharapkan, artinya model ini sudah efektif untuk memenuhi kebutuhan latihan dribble bolabasket untuk atlet pemula. Subyek yang diambil dalam penelitian adalah club yang dirasa masih belum memiliki prestasi dibanding dengan club yang lain. Hal ini memberikan satu pandangan bahwa ketika model ini diterapkan di club yang memiliki prestasi, maka pelaksanaannya akan lebih baik dan sempurna lagi.

Produk ini setelah dikaji mengenai beberapa kelemahan yang perlu pembenahan sesuai diatas maka dapat disampaikan beberapa keunggulan produk ini antara lain:

a. Atlet lebih aktif dalam mengikuti proses latihan.

b. Khasanah gerak atlet tetap pada konsep latihan yang mana atlet aktif dan bergerak dengan melakukan model latihan di mulai dari gerakan yang paling sederhana sampai pada gerakan yang sesuai dengan model latihan dribble.

c. Walaupun memerlukan sarana yang lebih banyak dari pada latihan konvensional tetapi konsep latihan yang di terapkan melalui model latihan mampu memberikan kemudahan bagi atlet dalam menguasai gerakan dribble secara baik dan benar.

d. Atlet terlihat gembira dan antusias dengan model latihan yang bervariasi.

e. Latihan melalui model gerakan dilakukan dari yang mudah ke yang sulit.

Tingkat permainan yang mengacu pada pembelajran sangat baik sehingga membuat atlet lebih bersemangat. Berdasarkan data yang diperoleh, dari hasil ujicoba kelompok kecil dan ujicoba lapangan serta pembahasan hasil penelitian, dapat disimpulkan bahwa:

a. Model latihan dribble bolabasket dapat dikembangkan dalam latihan dribble bolabasket untuk atlet pemula.

b. Model latihan dribble bolabasket efektif dapat meningkatkan hasil test dribble bolabasket untuk atlet pemula.

Berdasarkan kelebihan dan kelemahan model yang dikembangkan, keberagaman situasi dan kondisi dari tempat pengembangan, keberagaman kemampuan para pengguna model yang dikembangkan ini, maka perlu dirumuskan saran-saran dalam penggunaan model ini agar bisa berlangsung secara efektif dan efisien. Saran-saran itu adalah sebagai berikut: 
Produk pengembangan ini merupakan alat yang digunakan untuk melatih olahraga bolabasket pada atlet. Dalam pemanfaatannya sangat perlu mempertimbangkan situasi dan kondisi masing-masing club, tingkat keberagaman, pengalaman dan kompetensi pengguna, artinya produk ini tidak harus diterapkan secara sama, bentuk dan waktu permainan yang sama pula. Jadi generalisasi tidak berlaku dalam pemanfaatan produk ini, yang ada adalah produk ini hanya merupakan sebuah umpan bagi pelatih untuk mengembangkan bentuk model lain untuk mendapatkan tujuan latihan keterampilan dribble. Hasil pengembangan model latihan dribble bolabasket untuk atlet pemula yang lain sehingga keberadaan dan penggunaan model ini bisa tersebar lebih luas. Produk ini dapat dijadikan sebagai salah satu modul latihan keterampilan dribble bolabasket untuk atlet pemula. Produk ini masih memerlukan pengkajian dan uji coba secara intensif dan kontinyu, serta diberlakukan pada kancah yang mempunyai karakteristik lebih beragam, sebagai upaya untuk memperoleh umpan balik guna melakukan penyempurnaan. Subyek yang terlibat dalam kegiatan evaluasi dan uji coba lebih diperluas dengan melibatkan pelatih sebagai pengguna dan atlet sebagai subyek yang dilatih.

Pengkajian yang perlu dilakukan pada pengembangan yang selanjutnya adalah pada tingkat relevansi bentuk model yang diharapkan lebih bervariatif, inovatif dan merangsang atlet untuk lebih atusias dalam mengikuti proses latihan khususnya pada materi latihan keterampilan dribble bolabasket. Relevansi format penilaian dan latihan yang aktif, kreatif dan menyenangkan atas indikator dan deskriptornya serta bentuk instrumen tes untuk mengukur kemampuan atlet lebih rasional dan mudah dipahami serta mudah dipakai oleh pengguna.

\section{KESIMPULAN}

Berdasarkan data yang diperoleh, dari hasil ujicoba kelompok kecil dan ujicoba lapangan serta pembahasan hasil penelitian, dapat disimpulkan bahwa:

1. Model latihan dribble bolabasket dapat dikembangkan dalam latihan dribble bolabasket untuk atlet pemula.

2. Model latihan dribble bolabasket efektif dapat meningkatkan hasil test dribble bolabasket untuk atlet pemula.

\section{DAFTAR PUSTAKA}

Borg. W. R \& Gall, M. D, Educational Research: An Introduction. 4th Edition. New York: Longman Inc., 2007

Danny Kosasih, "Fundamental Basketball First Step To Win”. Semarang: Karangturi Media, 2010.

Harsono, Teori Dan Metodologi Pelatihan. Bandung: 2007.

Lubis, Johansyah. Panduan Praktis Penyusunan Program Latihan. Jakarta: PT. Rajagrafindo Persada, 2013.

Setyosari, Metode Peneltiian Pendidikan \& Pengembangan. Bandung: Kencana, 2013.

Sugiyono, Metodologi Peneltiian Pendidikan: Pendekatan Kuantitatif, Kualitatif, dan R\&D. Bandung: Alfabeta, 2013

Sukadiyanto, Pengantar Teori dan Metodologi Melatih Fisik. Bandung: Lubuk Agung, 2011 